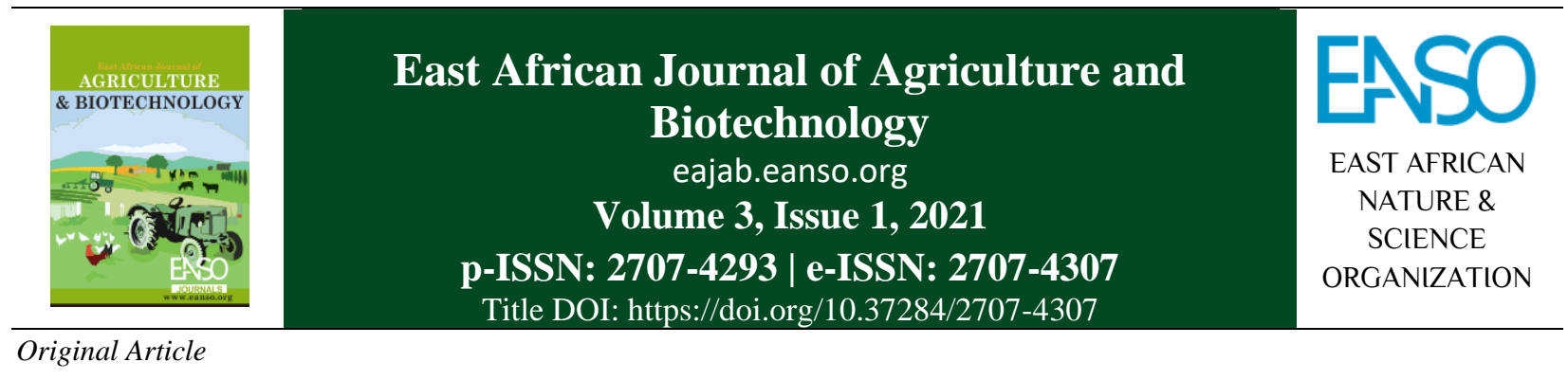

\title{
Evaluation of Ethiopian Common Bean (Phaseolus vulgaris L.) Genotypes Under Terminal Drought Stress Condition
}

\author{
Selamawit Abebe Gitore \\ Wachemo University, Durame Campus, P. O. Box 667, Hosaena, Ethiopia. \\ Correspondent, Email: abate4fam@gmail.com. \\ ORCID ID: https://orcid.org/0000-0003-0051-7387
}

Article DOI: https://doi.org/10.37284/eajab.3.1.311

\section{Date Published: ABSTRACT}

31 March 2021 The aim of this study was to evaluate twenty-five common bean genotypes for terminal drought stress. Simple lattice designs were used with two replications under stress and non-stress growing conditions on the field. The experiment was

Keywords: performed using irrigation water during the dry season (December-March). Up to flowering, the stress plots were irrigated and the non-stress plots were provided

Drought Stress, with water up to physiological maturity. Under both stress and non-stress

Genotypes, conditions, several plant characteristics related to yield were assessed. The generated data in this study was subject to analysis of variance (ANOVA) using

Common Bean, SAS software version 9.0.0. Data from non-stress (NS) and drought stress (DS)

Yield Components, treatments were compared to assess the effect of drought stress or water regime

Irrigation, on yield-related traits. In order to perform a combined analysis of variance, the

Variability datasets from the two treatments were combined (ANOVA). In this experiment, all the genotypes used showed significant differences in yield and some of the components of yield. For all the characteristics measured, except for flowering days, there were substantial variations between the two water treatments. There was no significant correlation between genotypes and water treatments for almost all the traits tested, with the exception of days to flowering, harvest index and root pulling resistance. Genotypes such as SER 125, MALB-67, MALB-65, MALB51 and MALB-3 performed better under the two water treatments on the basis of mean productivity (MP) and geometric mean (GM). Understanding the relationships between plant characteristics related to drought stress tolerance and their genetic variability for stress-related grain yield, especially terminal water stress conditions, should prompt common bean breeders to take better measurements of yield and more comprehensive features of drought response.

1 | This work is licensed under a Creative Commons Attribution 4.0 International License. 


\section{APA CITATION}

Gitore, S. A. (2021). Evaluation of Ethiopian Common Bean (Phaseolus vulgaris L.) Genotypes Under Terminal Drought Stress Condition. East African Journal of Agriculture and Biotechnology, 3(1), 82-90. https://doi.org/10.37284/eajab.3.1.311

\section{CHICAGO CITATION}

Gitore, Selamawit Abebe. 2021. "Evaluation of Ethiopian Common Bean (Phaseolus vulgaris L.) Genotypes Under Terminal Drought Stress Condition". East African Journal of Agriculture and Biotechnology 3 (1), 82-90. https://doi.org/10.37284/eajab.3.1.311.

\section{HARVARD CITATION}

Gitore, S. A. (2021) "Evaluation of Ethiopian Common Bean (Phaseolus vulgaris L.) Genotypes Under Terminal Drought Stress Condition”, East African Journal of Agriculture and Biotechnology, 3(1), pp. 82-90. doi: 10.37284/eajab.3.1.311.

\section{IEEE CITATION}

S. A. Gitore, "Evaluation of Ethiopian Common Bean (Phaseolus vulgaris L.) Genotypes Under Terminal Drought Stress Condition", EAJAB, vol. 3, no. 1, pp. 82-90, Mar. 2021.

\section{MLA CITATION}

Gitore, Selamawit Abebe. "Evaluation of Ethiopian Common Bean (Phaseolus vulgaris L.) Genotypes Under Terminal Drought Stress Condition". East African Journal of Agriculture and Biotechnology, Vol. 3, no. 1, Mar. 2021, pp. 82-90, doi:10.37284/eajab.3.1.311.

\section{INTRODUCTION}

Common bean is (Phaseolus vulgaris L.) one of the commonly cultivated plants. It is considered one of the most important grains for human feeding and is grown on around 26 million hectares worldwide (CIAT, 2001, Emam et al., 2010).

It is a food-safe and nutritious crop in Sub-Saharan Africa (SSA) and plays a wide dietary role; it supplies both rural and urban households with proteins, carbohydrates, essential elements and vitamins. The crop is expected to meet more than 50 percent of households' dietary protein requirements in sub-Saharan African (SSA) countries (Broughton et al., 2003). In Ethiopia, a common bean is an important food crop for legumes that many households eat nationwide. It is used in the country as a food security crop, but recently it has been regarded as a cash crop. It is only an important legume as a rotation crop in the Ethiopian lowland, especially in the rift valley where farmers grow white beans for export (EARO, 2001). It is a major food crop, especially in southern and eastern Ethiopia, where it serves as the primary source of dietary protein (Broughton et al., 2003; Graham and Vance, 2003). In several lowland and mid-altitude areas, it is also the most important cash crop and protein source for farmers. It is projected that the country's export earnings are over $85 \%$ of the pulse $2 \mid$ This work is licensed under a Creative Commons Attribution 4.0 International License. export earnings, exceeding that of other pulses such as lentils, horse (faba) bean and chickpea (Negash, 2007). Overall, the common bean ranks third in Ethiopia as an export product, contributing about 9.5 percent of the total agricultural export value (FAOSTAT, 2010).

One of the most critical and challenging issues for breeders, farmers and researchers are to boost crop production in harsh environments where drought is limiting (Asfaw \& Blair, 2014). In order to maintain the lives of millions of people in the region, it is important to grow more resilient and droughtresistant varieties that are adapted to the changing environment through testing lines for drought tolerance. The response of crops to drought can be investigated by evaluating characteristics associated with biotic stress tolerances at the physiological, cellular, biochemical and molecular levels (Praba et al., 2009). To this end, the assessment of common bean genotypes for drought stress is considered a key approach to crop improvement in order to reduce crop failure and improve the food security of small-scale farmers by genetically improving where these types of beans are mainly grown. 


\section{MATERIALS AND METHOD}

\section{Description of the Study Area}

The experiment was performed at the South Agricultural Research Institute's experimental station, Hawssa. At an altitude of $1700 \mathrm{~m}$ above sea level, Hawassa is located 7 x 03 'N, 38 x 30'E. The soil at this location is a well-drained Flovisol sandyloam (FAO classification) of $\mathrm{pH}$ 7.0.0. The site's annual average maximum and minimum temperatures are $26.9{ }^{\circ} \mathrm{C}$ and $12.4{ }^{\circ} \mathrm{C}$, respectively, and the average annual rainfall is $959 \mathrm{~mm}$. During the short "Belg" rainy season (March-May) and the long "Meher" rainy season (July-October), the precipitation at this site is bimodal with a combined seasonal amount of $296 \mathrm{~mm}$ and $444 \mathrm{~mm}$ respectively.

\section{Experimental Materials}

Twenty-five (25) common bean genotypes of distinct colors obtained from the Hawassa Agricultural Research Center and Southern Agricultural Research Institute (SARI), Ethiopia, are inbred lines and released varieties. In this analysis, the bean genotypes were initially introduced to Ethiopia by the Centro International de Agriculture Tropical (CIAT), Cali, and Colombia. Table 1.

Table 1: List of common bean genotypes used for evaluation under stress and non-stress conditions in Ethiopia, 2016

\begin{tabular}{llllll}
\hline S/No. & Genotype code & Gene pool & S/No. & Genotype code & Gene pool \\
\hline 1 & MALB-51 & Mesoamerican & 14 & MALB-132 & Mesoamerican \\
2 & MALB-56 & Mesoamerican & 15 & MALB-86 & Mesoamerican \\
3 & MALB-45 & Mesoamerican & 16 & MALB-122 & Mesoamerican \\
4 & MALB-29 & Mesoamerican & 17 & MALB-191 & Mesoamerican \\
5 & MALB-48 & Mesoamerican & 18 & MALB-193 & Mesoamerican \\
6 & MALB-138 & Mesoamerican & 19 & SER125 & Mesoamerican \\
7 & MALB-75 & Mesoamerican & 20 & MALB-155 & Mesoamerican \\
8 & MALB-67 & Mesoamerican & 21 & MALB-65 & Mesoamerican \\
9 & MALB-43 & Mesoamerican & 22 & MALB-77 & Mesoamerican \\
10 & MALB-3 & Mesoamerican & 23 & MALB-76 & Mesoamerican \\
11 & MALB-78 & Mesoamerican & 24 & MALB-143 & Mesoamerican \\
12 & MALB-13 & Mesoamerican & 25 & MALB-134 & Mesoamerican \\
13 & MALB-26 & Mesoamerican & & & \\
\hline
\end{tabular}

\section{Experimental procedures}

With two replications under stress and non-stress growth conditions on the field, a $5 \times 5$ simple lattice design was used. Up to flowering, the stress plots were irrigated and the non-stress plots were provided with water up to physiological maturity. The genotypes were grouped into four $2 \mathrm{~m}$ long rows using $60 \mathrm{~cm}$ and $10 \mathrm{~cm}$ inter-and intra-row spacing, respectively. Before flowering, all the plots received sufficient water and the non-stress experiment was supplied with water until physiological maturity. The experiment was performed using irrigation water during the dry season (December 2015-March 2016). Between planting and physiological maturity, soil moisture measurements were performed twice at depths of 0 $30,31-60$ and $61-90 \mathrm{~cm}$. To obtain the dry weight for each sampled plot, soil moisture was gravimetrically controlled by oven-drying the soil sample at 105 0C for 24 hours. A total of 9 irrigations were applied for drought treatment and supplementary irrigation was suspended after $80 \%$ of each plot had flowered until the crop was physiologically mature. But for the entire growing season, the non-stress plots were kept irrigated. So, there were a total of sixteen irrigations provided.

\section{Data Collection}

Days to flowering and maturity were recorded as the number of days from planting to when at least one open flower was in 50 percent of plants in a plot and

3 This work is licensed under a Creative Commons Attribution 4.0 International License. 
when at least 90 percent of their pods were dried out in 75 percent of plants in a plot. Other approximate parameters calculated are: plant height, number of pods per plant, number of seeds per pod, the total yield of seeds per plant, weight of 100 seeds, using five randomly selected plants per plot. Using a digital force gauge DS2, root pulling resistance was measured at harvest on 5 plants per plot (IMADA Inc.). By converting plot yield and adjusting seed moisture content to 10 percent, seed yield per hectare was obtained. Above Ground Biomass (AGB, gm plant-1) was considered to be the weight of the above-ground components (stem + leaves + pod wall + seeds) of randomly chosen plants drying at $60{ }^{\circ} \mathrm{C}$ for 24 hours. The Harvest Index (HI) was measured as the proportion of the seed weight of randomly selected plants at harvest time to the above-ground dry biomass (stalk + leaves + pod wall + seeds) x 100 . The geometric mean $(\mathrm{GM})$ based on seed yield was calculated as $\mathrm{GM}=(\mathrm{Ys} \mathrm{x}$ Yi) $1 / 2$ where Ys is the mean genotype seed yield under drought stress and $\mathrm{Yi}$ is the mean genotype seed yield grown under non-stress. Mean productivity (MP) in the stressed (Ys) and nonstressed (Yp) conditions was determined as the average genotype yield.

Geometric mean (GM): (Fernandez, 1992)

$$
\mathrm{GM}=\left(\mathrm{Yp}^{*} \mathrm{Ys}\right)^{1 / 2}
$$

\section{Data Analysis}

The data produced in this study was subject to variance analysis (ANOVA) using SAS software version 9.0.0. Using the mean values, simple correlation coefficients between traits were calculated. Using Duncan's multiple range test at the $p<0.05$ stage, the substantially different means were compared.

\section{RESULT AND DISCUSSION}

\section{Analysis of Variance}

In order to perform a cumulative analysis of variance, the datasets from the two treatments were combined (ANOVA). For all the characteristics assessed excluding days for flowering, there were significant differences between the two water regimes for (Table 2). For all the characteristics excluding grain yield and 100 seed weight, there were also major variations between the genotypes across the two habitats. There was no major association between genotypes and water regimes for almost all the traits examined, except for flowering, harvest index and root pulling resistance for days. Table 2: Summary of ANOVA of treatments effects on 25 genotypes of common bean Lines subjected to post-flowering water stress.

Mean productivity (MP) (Rosielle and Hambline, 1981) $\quad \mathrm{MP}=(\mathrm{Ys}+\mathrm{Yp}) / 2$

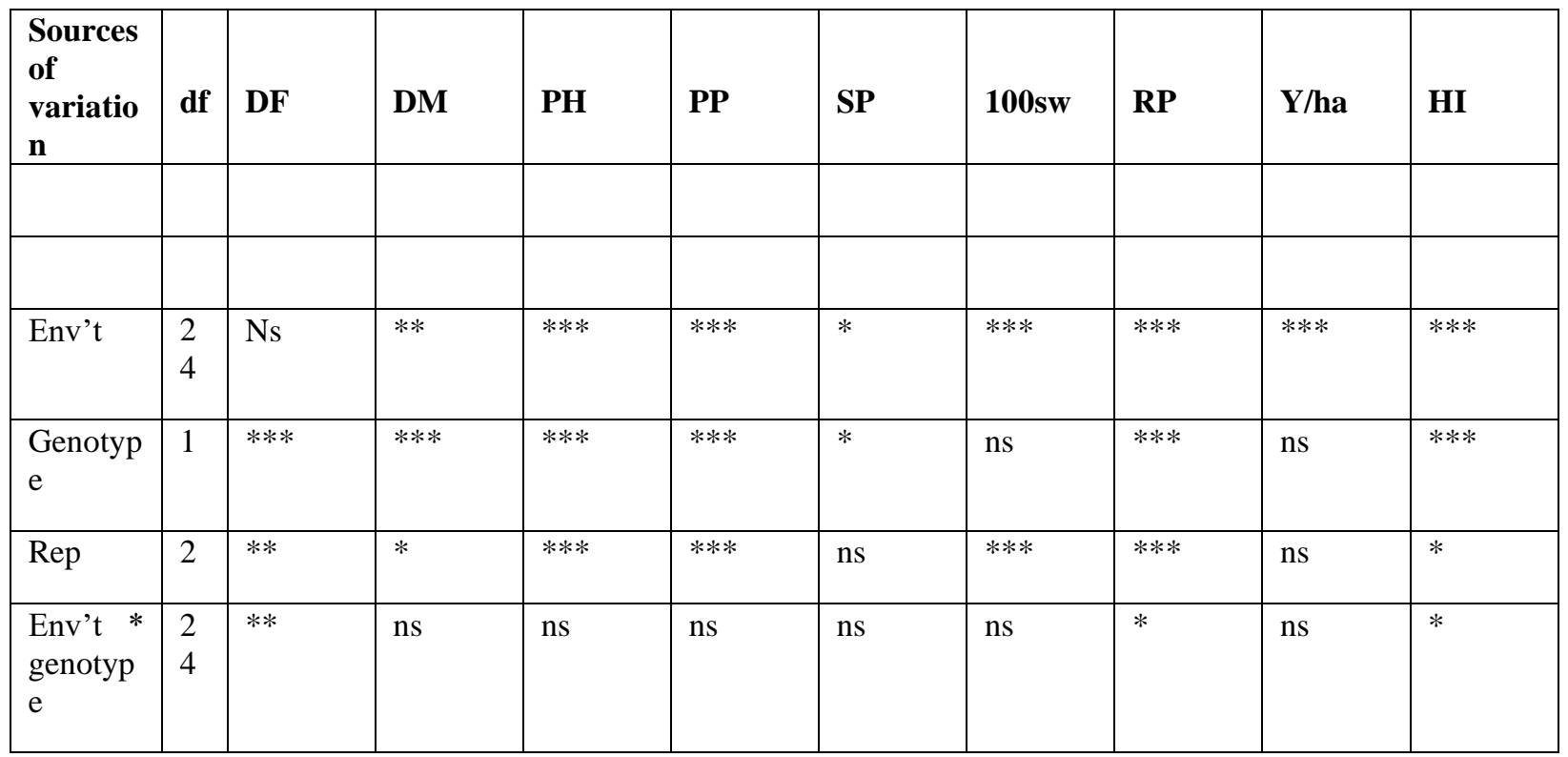

4 | This work is licensed under a Creative Commons Attribution 4.0 International License. 
East African Journal of Agriculture and Biotechnology, Volume 3, Issue 1, 2021

Article DOI: https://doi.org/10.37284/eajab.3.1.311

\begin{tabular}{|c|c|c|c|c|c|c|c|c|c|c|}
\hline $\begin{array}{l}\text { Envt * } \\
\text { rep }\end{array}$ & $\begin{array}{l}4 \\
8\end{array}$ & Ns & ns & $* * *$ & $* * *$ & ns & ns & $* *$ & ns & ns \\
\hline $\begin{array}{l}\text { Genotyp } \\
\text { e * rep }\end{array}$ & 2 & Ns & ns & ns & $\mathrm{ns}$ & ns & $\mathrm{ns}$ & $\mathrm{ns}$ & $\mathrm{ns}$ & $*$ \\
\hline error & $\begin{array}{l}4 \\
8\end{array}$ & & & & & & & & & \\
\hline $\mathrm{R}^{2}$ & & $\begin{array}{l}0.88625 \\
8\end{array}$ & $\begin{array}{l}0.80567 \\
8\end{array}$ & $\begin{array}{l}0.88305 \\
8\end{array}$ & $\begin{array}{l}0.91843 \\
9\end{array}$ & $\begin{array}{l}0.72315 \\
0\end{array}$ & $\begin{array}{l}0.80212 \\
0\end{array}$ & $\begin{array}{l}0.97827 \\
1\end{array}$ & $\begin{array}{l}0.79216 \\
8\end{array}$ & $\begin{array}{l}0.84684 \\
7\end{array}$ \\
\hline CV (\%) & & $\begin{array}{l}11.7066 \\
4\end{array}$ & $\begin{array}{l}6.70645 \\
2\end{array}$ & $\begin{array}{l}14.3329 \\
8\end{array}$ & $\begin{array}{l}20.6834 \\
1\end{array}$ & $\begin{array}{l}11.7136 \\
8\end{array}$ & $\begin{array}{l}24.5126 \\
3\end{array}$ & $\begin{array}{l}13.0466 \\
8\end{array}$ & $\begin{array}{l}37.1857 \\
6\end{array}$ & $\begin{array}{l}12.4207 \\
4\end{array}$ \\
\hline & & & & & & & & & & \\
\hline & & & & & & & & & & \\
\hline
\end{tabular}

PP: Number of pods per Plant; DF: days to $50 \%$ flowering; DM: days to maturity

PP: Number of pods per Plant; DF: days to $50 \%$ flowering; DM: days to maturity

SP: Number of seeds per Pod; PH: plant height; 100sw: hundred seed weight

RP: root pooling resistance $Y$ t/ha: yield per hectare; $H I$ : Harvest index

Level of significance $\mathrm{ns}, *, * *, * * *$ denoting non-significant, significant at $\mathrm{p} \leq 0.05$ and at $\mathrm{p} \leq 0.001$.

\section{Effect of water stress on grain yield and yield components of twenty-five common bean genotypes}

There were highly significant differences among the genotypes for grain yield (Table 3 ). The mean grain yield values across all genotypes under non-stress and stress environments were 3.07 and 2.41 tha $^{-1}$, respectively (Table 3 ). On the basis of seed yield performance under DS and NS conditions, the 25 genotypes could be classified into four categories. In the first category were genotypes with greater performance than the check-in both environments, namely MALB-67, MALB-51, MALB-143, MALB-78 and MALB-65. In the second yield performance category were genotypes with the lowest yield in the DS and NS treatments, namely MALB-77, MALB-138, MALB-13 and MALB-43. The third category contained genotypes that had high yield (higher than the check) in the DS treatment but had low yields (lower than the check) in the NS treatment. The genotypes are MALB-67 which had the highest yield under stressed condition and MALB-56, MALB-29, MALB-48, MALB-76,
MALB-86, MALB-193, MALB-3, MALB-43, MALB-26, MALB-191, MALB-75, MALB-13, MALB-138, MALB-132, MALB-45, MALB-155, MALB-122, MALB-134 and MALB-77. The fourth category included genotypes that responded to the NS condition but had correspondingly lower yield in the DS condition, namely MALB-78, MALB-56, and MALB-134 and MALB-143. The yield varied from 2.00 to $4.17 \mathrm{t} / \mathrm{ha}$ and 1.15 to $4.37 \mathrm{t} / \mathrm{ha}$ under non-stressed and water-stressed conditions respectively (Table 3 ). The highest grain yield under non-water stressed condition was obtained from MALB-51 (4.17 t/ha) followed by MALB-78 (4.16 t/ha), MALB-143 (3.78 t/ha), then SER 125 (3.33 $\mathrm{t} / \mathrm{ha}$ ) and the lowest grain yield was obtained from MALB-77 (2.00 t/ha), followed by MALB-155 $(2.15 \mathrm{t} / \mathrm{ha})$. The highest grain yield under waterstressed conditions was obtained from MALB-67 (4.37 t/ha) followed by SER 125 (3.63 t/ha) and MALB-48 (2.57 t/ha) and the lowest grain yield was obtained from MALB-193 (1.15 t/ha). SER 125 recorded the highest hundred seed weight of 40.15 $\mathrm{g}$ while MALB-51 recorded the lowest hundred seed weight of $31.15 \mathrm{~g}$ under non-water stressed conditions. Also, SER 125 recorded the highest

5 | This work is licensed under a Creative Commons Attribution 4.0 International License. 
East African Journal of Agriculture and Biotechnology, Volume 3, Issue 1, 2021

Article DOI: https://doi.org/10.37284/eajab.3.1.311

hundred seed weight (41.66 g) while MALB-155 recorded the lowest $(22.2 \mathrm{~g})$ underwater-stressed conditions (Table 4). SER 125recorded the highest number of pods per plant (38) followed by MALB143 (33) and MALB-191 (33) under non-stressed conditions. MALB-56 recorded the highest number of pods/plant (33) while MALB-191 recorded the lowest value (14) under water-stressed condition

Table 3: Mean values seed yield of twenty-five common bean genotypes under stressed and non-stressed environments. Plants were stressed after flowering.

\begin{tabular}{llll}
\hline & GENOTYPES & Yp/ha & Ys/ha \\
\hline 1 & MALB-56 & 3.33 & 1.52 \\
2 & SER 125 & 3.63 & 3.12 \\
3 & MALB-29 & 3.28 & 2.42 \\
4 & MALB-48 & 2.79 & 2.57 \\
5 & MALB-76 & 2.94 & 1.39 \\
6 & MALB-86 & 2.80 & 2.16 \\
7 & MALB-193 & 2.89 & 1.15 \\
8 & MALB-3 & 3.08 & 2.77 \\
9 & MALB-43 & 2.85 & 1.75 \\
10 & MALB-51 & 4.17 & 2.08 \\
11 & MALB-26 & 3.02 & 2.10 \\
12 & MALB-143 & 3.78 & 1.72 \\
13 & MALB-78 & 4.16 & 1.44
\end{tabular}

\begin{tabular}{clll}
\hline & GENOTYPES & Yp/ha & Ys/ha \\
\hline 14 & MALB-191 & 3.34 & 1.68 \\
15 & MALB-75 & 3.07 & 2.73 \\
& & & \\
16 & MALB-13 & 2.34 & 1.36 \\
17 & MALB-65 & 3.66 & 2.67 \\
18 & MALB-138 & 3.57 & 1.15 \\
19 & MALB-132 & 2.79 & 2.07 \\
20 & MALB-45 & 2.41 & 2.54 \\
21 & MALB-155 & 2.15 & 2.23 \\
22 & MALB-134 & 3.00 & 2.67 \\
23 & MALB-122 & 2.90 & 2.35 \\
24 & MALB-77 & 2.00 & 1.58 \\
25 & MALB-67 & 2.84 & 4.37 \\
Grand mean & $\mathbf{3 . 0 7}$ & $\mathbf{2 . 1 4}$ \\
\hline
\end{tabular}

Ys ha $^{-1}$ : Yield under stressed condition per hectare

Yp ha-1: Yield under non stressed condition per hectare

\section{Effect of Drought stress on seed yield}

Up-regulated or down-regulated trait expression of drought stress in the varieties based on which measurement of drought tolerance was considered, the average seed yield was decreased by 32.3 percent, the number of pods per plant by $27.4 \%$, the number of seeds per pod by $8.9 \%$, and the weight of 100 seeds by $23.5 \%$ (Table 4 ).

Table 4: Significance of treatment, genotype, and genotype $x$ treatment effects for traits evaluated

\begin{tabular}{lllllllll}
\hline \multirow{2}{*}{ Trait } & CV\% & \multicolumn{2}{c}{ Grand Means } & \multicolumn{2}{c}{ Max Value } & \multicolumn{2}{c}{ Min Value } & Percent \\
\cline { 3 - 8 } & & DS & NS & DS & NS & DS & NS & Reduction (\%) \\
\hline DF & 11.7 & 42.9 & 49.8 & 49 & 57.5 & 40 & 44.5 & 13.9 \\
DM & 6.7 & 75.7 & 73.4 & 80 & 77.5 & 74 & 70 & -3.1 \\
PH & 14.3 & 39.1 & 43.3 & 57.1 & 57.2 & 31 & 32.7 & 9.7 \\
PP & 20.7 & 18 & 24.8 & 25.9 & 37.6 & 13.6 & 16 & 27.4 \\
SP & 11.7 & 5.1 & 5.6 & 5.8 & 6.3 & 4.3 & 4.8 & 8.9 \\
100sw & 24.5 & 26.4 & 34.5 & 41.7 & 43.1 & 21.8 & 30.3 & 23.5
\end{tabular}

6 | This work is licensed under a Creative Commons Attribution 4.0 International License. 
East African Journal of Agriculture and Biotechnology, Volume 3, Issue 1, 2021

Article DOI: https://doi.org/10.37284/eajab.3.1.311

\begin{tabular}{lllllllll} 
RPR & 13 & 49.9 & 24.4 & 71.76 & 36.1 & 28.9 & 13.27 & -104.5 \\
Y kg ha & 37.2 & 2.1 & 3.1 & 4.4 & 4.2 & 1.1 & 2 & 32.3 \\
HI & 12.4 & 4.2 & 12.5 & 10 & 24.1 & 1.8 & 7.6 & 66.4 \\
\hline
\end{tabular}

$\mathrm{DF}=$ days to flowering, $\mathrm{DM}=$ days to maturity, $\mathrm{PH}=$ plant height, $\mathrm{PP}=$ number of pods/ plants,

$\mathrm{SP}=$ number of seed per plant, 100sw=hundred seed weight, $\mathrm{RP}=$ root pooling resistance,

$\mathrm{Y} \mathrm{ha}{ }^{-1}=$ yield per kilogram per hectare and $\mathrm{HI}=$ harvest index; NS = non-stress; DS = drought stress

For certain characteristics, the significance of genotypes, environments, and genotypes by environmental interaction showed that the genotypes' output across the two water regimes was not stagnant and non-responsive, but rather adaptive. This is in line with the results of Asfaw \& Blair (2014), who reported differential reactions to stressed and non-stressed drought conditions of common bean varieties. Generally, yield component characteristics are strong measures of overall drought stress.

\section{CONCLUSION}

The phenotypic expression of seed yield components (number of pods per plant, number of seeds per pod and 100-seed weight) of common beans plays an important role in environmental conditions such as drought stress. In order to identify drought-tolerant genotypes that can be used as parents in future breeding programmes for drought tolerance in common beans, this study was carried out to investigate the response of twentyfive genotypes of common beans to drought stress. Genotypes such as SER 125, MALB-67, MALB-65, MALB-51 and MALB-3 had better yield under the two water regimes based on mean productivity (MP) and geometric mean (GM). Understanding the relationships between plant characteristics related to drought stress tolerance and their genetic variability for stress-related grain yield, especially terminal water stress conditions, should prompt common bean breeders to take better measurements of yield and more comprehensive features of drought response.

\section{ACKNOWLEDGMENT}

I am grateful to the administrative staff of Hawassa agricultural research center for the provision of land and irrigation facilities for my fieldwork. I would like to thank all the staff at Hawassa research center livestock and bee breeding research case team members for providing a good atmosphere and who constantly welcome me every time I visited the center.

\section{REFERENCES}

Asfaw, A., Blair, P.S, and Matthew. W. (2014). Quantification of drought tolerance in Ethiopian common bean varieties. Journal of agricultural sciences,5(2), 124-139.

Broughton, W. J., Hern'andez, G., Blair, M., Beebe, S., Gepts, P., and Vanderleyden, J. (2003).

Beans (Phaseolus spp) - model food legumes. Plant and Soil, 252, 55-128

CIAT. (2001). 2001 Annual report in respective "Getting the better of climate change". Cali, Colombia.

Darkwa, K., Ambachew, D., Mohammed, H., Asfaw, A., and Blair, M. W. (2016). Evaluation of common bean (Phaseolus vulgaris L.) genotypes for drought stress adaptation in Ethiopia. The Crop Journal. http://doi.org/10.1016/j.cj.2016.06.007

EARO. (2001). 1999/2001 report of Melkasa Agricultural Research Center, Ethiopian Agricultural Research Organization (EARO), Melkasa. Retrieved fromhttp://www.fao.org/3/i1786e/i1786e00.pdf

Emam, Y., Shekoofa,A., Salehi, F. and Jalali, A.H. (2010). Water Stress Effects on Two Common Bean Cultivars with Contrasting Growth HabitsAmerican-Eurasian J. Agric. \& Environ. Sci., 9 (5): 495-499, 2010 ISSN 1818-6769

7 | This work is licensed under a Creative Commons Attribution 4.0 International License. 
FAOSTAT. (2010). Food and Agriculture Organization (FAO). Retrieved from www.fao.org

Fernandez, G.C.J. (1992). Effective Selection Criteria for Assessing Stress Tolerance. In: Kuo, C.G., Ed., Proceedings of the International Symposium on Adaptation of Vegetables and Other Food Crops in Temperature and Water Stress, AVRDC Publication, Tainan, 257-270.

Grahams, P. and Vance, C. (2003). Legumes: importance and constraints to great use. Plant phsiol. 131:872-877

Negash, R. (2007). Determinants of adoption of improved haricot bean production package in Alaba special woreda, southern Ethiopia. MSc Thesis, Haramaya University.

Praba, M. L., Cairns J. E., Babu, R.C and Lafitt, H. R. (2009). Identification of Physiological Traits Underlying Cultivar Differences in Drought Tolerance in Rice and Wheat. Journal of Agronomy and Crop Science, 195,30-46

Rosielle, A.A. and Hamblin, J. (1981). Theoretical aspects of selection for yield in stress and nonstress environments. Crop Science, 21 (6). 943946.

$8 \mid$ This work is licensed under a Creative Commons Attribution 4.0 International License. 